\title{
A PROGNOSTIC AND SOCIAL STUDY
}

\author{
BY
}

\section{ARTHUR HARRIS, INGE LINKER, VERA NORRIS, AND MICHAEL SHEPHERD}

From the Bethlem Royal Hospital, the Maudsley Hospital, and the Institute of Psychiatry of the University of London

\section{INTRODUCTION}

This paper reports the findings of a follow-up study of 126 schizophrenic in-patients who received insulin coma therapy at the Maudsley Hospital during the years 1945 - 1948 inclusive, these appearing to be a representative group with a reasonably favourable outlook. The case papers relating to these patients gave detailed information about their medical history and in-patient care at this hospital. The individual patients were followed up for 5 years after discharge from the Maudsley Hospital, strenuous efforts being made to obtain complete information about their fate during this period. Many of the patients ( 38 per cent.) and their relatives ( 58 per cent.) were interviewed by the two clinicians (A. H. and M. S.) and/or the psychiatric social worker (I. L.). Medical reports relating to part or all of the follow-up period were available for 86 per cent. Only four patients and ten relatives refused an interview, usually on the grounds that the psychotic episode was over and they were unwilling to raise the matter again. In four cases contact with the patients or relatives could only be made by letter. A social case history and a medical report were obtained for those persons who were found to be in hospital. Two died early in the follow-up period and for one an assessment of the clinical state was not available. Numbers in some of the Tables therefore amount to only 123 .

Relation of Time SPent In Hospital during 5-Year Period to Outcome as Observed at the END OF 5 YEARS.- Statistical studies in which the duration of stay in hospital is used as an index are common, e.g. Fuller and Johnston (1931), Malzberg (1940), Dunham and Meltzer (1946), Harris and Lubin (1952), Harris and Norris $(1954 ; 1955)$, and Ødegaard (1954), to mention but a few from both sides of the Atlantic. The results are often criticized on the grounds that a person may be out of hospital but yet show marked mental symptoms.
This is of course true, but does not necessarily conflict with the hypothesis implicit in such studies that the length of time in hospital during a specified period is a measure of the intractability or persistence of the illness and that persons who suffered from milder or briefer attacks are less likely to have residual disabilities.

It was possible in this study to measure the course of illness by three indices:

(1) Total time spent in hospital during 5 years followup;

(2) Clinical condition of patient at the end of 5 years, i.e. whether recovered, showing residual defect or mild psychotic symptoms, unchanged, or worse;

(3) Social condition at the end of 5 years, as indicated by independent life, dependence on others although out of hospital, or in-patient residence.

Thus each individual patient was scored in three ways, and we examined the data (Table I) to see if the three indices gave similar assessments. It should be noted here that, whereas duration of stay in hospital and social independence were items which could be more or less objectively rated independently of each other, the clinical assessment of recovery was subjective and the assessors' ratings must have been influenced by knowledge of the patient's social adaptation. In short, we found that, of those patients who did not experience any hospital care during the follow-up period, 73.6 per cent. were rated clinically as recovered or improved and socially as independent. Of persons who spent a total of less than one year in hospital, 67.8 per cent. were recovered or improved and independent and 9.7 per cent. were in hospital. Of those who spent more than one year in hospital, only $15 \cdot 5$ per cent. were rated clinically as recovered or improved and socially independent whereas 67 per cent. were in hospital. These differences, shown in detail in Table I, were highly significant, and the probability that they resulted from chance effects alone is less than 1 in 10,000 . 
TABLE I

COMPARISON OF LENGTH OF STAY IN HOSPITAL DURING FOLLOW-UP PERIOD WITH CLINICAL AND SOCIAL ASSESSMENT OF PATIENTS' OUTCOME

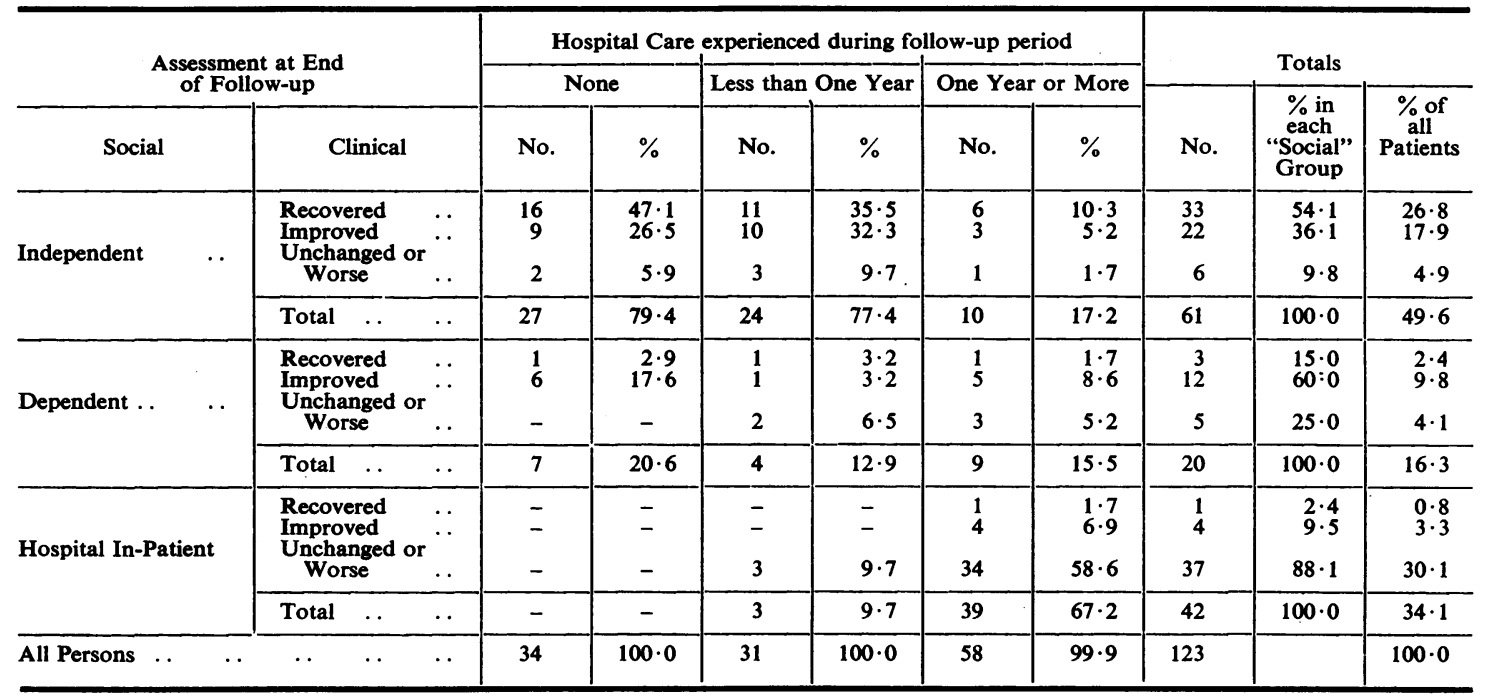

$\chi^{2}$ Significance Tests, in each case using the three Length-of-Stay Groups and:
(a) three Social Outcome Groups
(b) nine Assessment Groups
$\chi^{2}=59.4 ; n=4 ; P<0.001$
$\chi^{2}=66.4 ; n=16: P<0.001$
$\chi^{2}=35.9 ; n=4 ; P<0.001$

It seems justifiable to conclude, therefore, that largescale statistical studies, in which prognosis is assessed solely by duration of hospital stay, do, in fact, give a reliable assessment of outcome. The results of this detailed study confirmed those found previously by Harris and Norris $(1954 ; 1955)$. Age and sex had no marked influence on outcome. The numbers of patients in the diagnostic sub-groups here were as follows:

\author{
Simple, 14; \\ Paranoid, 52; \\ Hebephrenic, 31; \\ Catatonic, 9; \\ Atypical, 20.
}

The outcome in the atypical group was somewhat superior to that in the others but not to a statistically significant extent. Investigation of the individual signs according to a plan used previously by Harris and Norris (1954) confirmed the finding that deterioration of affect was the only prognostic indicator of importance (Table II, opposite). Deterioration of affect was more commonly found among the long-stay cases than among others, and was more often associated with marked evidence of psychosis at the end of the follow-up period. Persons exhibiting this sign were not often found to be socially independent.
Effect of Certain Features of Treatment on: OuTCOME.-The number of comas and the insulin dosage were obtained from the case records and are shown in Table III (opposite). No association could be demonstrated between the outcome and the number of comas, insulin dosage, or gain in weight during treatment, all of which have been thought at times to be of some prognostic importance (Mayer-Gross, Slater, and Roth, 1954). This finding is of little significance, since there are so many other variables which cannot be accounted for.

Effect of Social Factors on Outcome.-Previous work on this subject is scanty. Mettler, Crandell, Wittenborn, Litten, Feiring, and Carpenter (1954), in an inquiry into the fate of psychotic patients subjected to leucotomy or similar procedures, assessed their subjects on the Crutcher environmental rating scale and compared the ratings with outcome. They concluded that "while a favourable environmental rating is no guarantee of discharge, an unfavourable one tends to militate against it". Orr, Anderson, Martin, and Philpot (1955) found that "possession of immediate family" influenced. the chance of discharge favourably. Hollingshead and Redlich (1954a, b) found that, on the average, upper class patients spent less total time 
TABLE II

OUTCOME OF PERSONS WITH DETERIORATION OF AFFECT COMPARED WITH THAT OF PERSONS NOT SHOWING THIS SIGN

\begin{tabular}{|c|c|c|c|c|c|c|c|c|c|c|}
\hline \multirow{2}{*}{\multicolumn{6}{|c|}{ Prognostic Indices }} & \multicolumn{4}{|c|}{ Deterioration of Affect } & \multirow{3}{*}{$\begin{array}{l}\text { Statistical } \\
\text { Significance }\end{array}$} \\
\hline & & & & & & \multicolumn{2}{|c|}{ Present } & \multicolumn{2}{|c|}{ Absent } & \\
\hline & & & & & & Observed & Expected & Observed & Expected & \\
\hline \multirow[t]{2}{*}{$\begin{array}{l}\text { Time in Hospital during } \\
\text { Follow-up Period (yrs) }\end{array}$} & $\begin{array}{l}\text { Nor } \\
\text { Les } \\
1-2 \\
2 \text { an }\end{array}$ & $\begin{array}{l}\text { han } 1 \\
\text { over }\end{array}$ & $\begin{array}{l}\cdots \\
\cdots \\
\cdots\end{array}$ & $\begin{array}{l}\cdots \\
\cdots \\
\cdots\end{array}$ & $\begin{array}{l}\cdots \\
\cdots \\
\cdots\end{array}$ & $\begin{array}{r}6 \\
11 \\
9 \\
22\end{array}$ & $\begin{array}{r}13 \cdot 2 \\
12 \cdot 0 \\
8 \cdot 5 \\
14 \cdot 3\end{array}$ & $\begin{array}{l}28 \\
20 \\
13 \\
15\end{array}$ & $\begin{array}{l}20 \cdot 8 \\
19 \cdot 0 \\
13 \cdot 5 \\
22 \cdot 7\end{array}$ & \multirow[t]{2}{*}{$\begin{array}{c}\text { Degrees of } \\
\text { Freedom }=3 \\
\mathscr{\chi}^{2}=13 \cdot 1 \\
P<0.005\end{array}$} \\
\hline & All & $\ldots$ & $\ldots$ & $\cdots$ & $\cdots$ & 48 & $48 \cdot 0$ & 76 & $76 \cdot 0$ & \\
\hline \multirow[t]{2}{*}{ Clinical Status } & $\begin{array}{l}\text { Rec } \\
\text { Resi } \\
\text { Mil } \\
\text { No } \\
\text { Wor }\end{array}$ & $\begin{array}{l}\text { vered } \\
\text { ual Defe } \\
\text { Psychoti } \\
\text { hange } \\
\text {.. }\end{array}$ & $\begin{array}{l}\text { ect } \\
\text { ic Sym } \\
\ldots \\
\ldots\end{array}$ & $\begin{array}{l}\ldots \\
\therefore \\
\ldots \\
\ldots\end{array}$ & $\begin{array}{l}\cdots \\
\cdots \\
\cdots \\
\cdots\end{array}$ & $\begin{array}{r}4 \\
10 \\
8 \\
15 \\
11\end{array}$ & $\begin{array}{r}14 \cdot 4 \\
7 \cdot 4 \\
7 \cdot 4 \\
9 \cdot 4 \\
9 \cdot 4\end{array}$ & $\begin{array}{r}33 \\
9 \\
11 \\
9 \\
13\end{array}$ & $\begin{array}{l}22.6 \\
11.6 \\
11.6 \\
14.6 \\
14.6\end{array}$ & \multirow[t]{2}{*}{$\begin{array}{l}\text { Degrees of } \\
\text { Freedom }=4 \\
\stackrel{\chi}{P}=17.9_{P}^{2}=0.005\end{array}$} \\
\hline & All & $\ldots$ & $\ldots$ & $\ldots$ & $\ldots$ & 48 & $48 \cdot 0$ & $75^{*}$ & $75 \cdot 0$ & \\
\hline \multirow[t]{2}{*}{ Social Status } & $\begin{array}{l}\text { Inde } \\
\text { Dep } \\
\text { Hos }\end{array}$ & $\begin{array}{l}\text { endent } \\
\text { ndent by } \\
\text { ital Pati }\end{array}$ & ut out & $\ddot{\text { of Host }}$ & pital & $\begin{array}{l}13 \\
13 \\
22\end{array}$ & $\begin{array}{r}24 \cdot 0 \\
7 \cdot 7 \\
16 \cdot 3\end{array}$ & $\begin{array}{r}49 \\
7 \\
20\end{array}$ & $\begin{array}{l}38 \cdot 0 \\
12 \cdot 3 \\
25 \cdot 7\end{array}$ & \multirow{2}{*}{$\begin{array}{c}\text { Degrees of } \\
\text { Freedom }=2 \\
\chi^{2}=17 \cdot 4 \\
P<0.0001\end{array}$} \\
\hline & All & $\ldots$ & $\ldots$ & $\ldots$ & $\ldots$ & 48 & $48 \cdot 0$ & 76 & $76 \cdot 0$ & \\
\hline
\end{tabular}

- For one patient no information was available on this point

TABLE III

INSULIN TREATMENT GIVEN TO PATIENTS INCLUDED IN THIS STUDY

\begin{tabular}{|c|c|c|c|c|}
\hline \multicolumn{3}{|c|}{ Comas } & $\begin{array}{l}\text { Number } \\
\text { of Patients }\end{array}$ & $\begin{array}{c}\text { Per- } \\
\text { centage }\end{array}$ \\
\hline \multirow[t]{2}{*}{$\begin{array}{l}\text { Number of Comas } \\
\text { Received }\end{array}$} & $\begin{array}{l}\text { Under } 20 \\
20-29 \quad \ldots \\
30-39 \quad \ldots \\
40 \text { and over }\end{array}$ & $\begin{array}{l}\cdots \\
\cdots \\
\cdots\end{array}$ & $\begin{array}{l}45 \\
25 \\
34 \\
20\end{array}$ & $\begin{array}{l}36 \cdot 3 \\
20 \cdot 2 \\
27 \cdot 4 \\
16 \cdot 1\end{array}$ \\
\hline & All Patients & . & 124 & $100 \cdot 0$ \\
\hline \multirow[t]{2}{*}{$\begin{array}{l}\text { Maximum Dosage } \\
\text { of Insulin Required } \\
\text { to induce Coma } \\
\text { (units) }\end{array}$} & $\begin{array}{l}\text { Under } 200 \\
200-299 \ldots \\
300-399 \ldots \\
400-499 \ldots \\
500 \text { and over }\end{array}$ & $\begin{array}{l}\cdots \\
\cdots \\
\cdots \\
\cdots\end{array}$ & $\begin{array}{l}23 \\
27 \\
28 \\
20 \\
18\end{array}$ & $\begin{array}{l}19 \cdot 8 \\
23 \cdot 4 \\
24 \cdot 1 \\
17 \cdot 2 \\
15 \cdot 5\end{array}$ \\
\hline & All Patients & . & 116 & $100 \cdot 0$ \\
\hline
\end{tabular}

Excludes eight patients who never went into coma

in hospital than lower class patients, and that they had more frequent but much shorter stays in hospital. The same investigators $(1953,1954 a, b)$ found that the incidence of schizophrenia was higher in the lower social classes. Hollingshead, Ellis, and Kirby (1954) found that schizophrenics were socially more mobile than the average. All the above papers emanate from the U.S.A. where social conditions differ in important respects from those in Great Britain.

The psychiatric social worker (I. L.) tried to secure an interview, usually lasting from 1 to 2 hours, with the relatives, the patient, or both. The patients were often suspicious and the relatives anxious during the interview, so that repeated visits were undesirable, and in fact proved unnecessary. Spontaneous talk was encouraged and prompting avoided, although sometimes it was necessary to guide the conversation along subjects relevant to this inquiry. In particular, we were interested in the reasons for readmission to hospital, and for seeking or avoiding medical help. We wished to assess the part played by the relatives in the curtailment or extension of hospital care. We sought to find the effect on the relatives of dangerous, suicidal, or socially embarrassing behaviour, e.g. audible conversations with hallucinatory voices, which would be noticed by persons outside the family circle. The activities of the expatient were recorded with reference to his work, and social and leisure-time activities. As far as possible facts rather than opinions were recorded.

\section{RESULTS}

(1) Relationship between Clinical and Social Assesment of Outcome.-As will be seen from Table I, the clinical assessment of the patient corresponded in the majority of cases to his social assessment:

(i) earning his own living and independent,

(ii) dependent on his family, friends, or social agencies,

(iii) in hospital

The recovered patient still in hospital on the last day of the follow-up period was awaiting discharge. The differences between the social outcome groups in respect of clinical outcome are highly significant $\left(x^{2}>24 ; n=4 ; P<0.0001\right)$, and on the whole persons who were judged to be well by social standards were likewise assessed by clinical standards. 
(2) Effect of Dangerous or Socially Embarrassing Behaviour on Possibility of Discharge.-It seemed likely to us that persons who had exhibited in the course of their illness suicidal or homicidal tendencies or features that made their presence an embarrassment to their families might be less readily accepted at home. Our results supported this view, but it was surprising, nevertheless, to find that relatives pressed for the discharge of a large proportion of the difficult patients.

Of 65 patients who stayed in hospital for less than one year during the follow-up period, 24 (37 per cent.) had displayed some definite kind of socially embarrassing behaviour and six of these had been dangerous to themselves or others.

In all, there were 41 patients who had been dangerous to themselves and/or to others (nineteen of whom also presented embarrassing symptoms), but the families of 22 (54 per cent.) of these themselves sought their discharge.

Of 36 persons who exhibited socially embarrassing features, the families of 23 (64 per cent.) wanted them home.

Of 46 patients who did not exhibit any of these symptoms, 39 (84 per cent.) had relatives who pressed for their discharge.

In the series as a whole, the relatives of 68 per cent. took active steps to secure discharge. The differences with respect to family pressure for discharge between patients who were dangerous or socially embarrassing and those who were not are highly significant $\left(\chi^{2}=10 ; n=2 ; P<0.01\right)$; the discharge of those patients who were dangerous either to themselves or others or who had socially embarrassing symptoms was not sought after to the same extent as that of those who did not exhibit such features.

It is not therefore surprising to find that, among 65 patients who either did not go into hospital during the follow-up period or who spent less than one year in hospital, a large proportion ( 83 per cent.) had relatives who had sought their discharge, and that among the long-stay group ( 2 years or more in hospital) of 37 patients, only 43.2 per cent. had relatives who were seeking their discharge. Among the intermediate group of 21 patients (between 1 and 2 yrs in hospital) two-thirds had relatives active in this respect.

These differences are highly significant $(P<0.001)$. Associated with this finding is another highly significant result; among 41 persons dangerous to themselves or to others, 59 per cent. were found in the long-stay group, of the 36 with socially embarrassing symptoms, 31 per cent., and of the 46 with no such symptoms at all only 4 per cent. were found to have

spent 2 or more years in hospital during the followup period $(P<0.001)$.

(3) Social Class*.-In our sample, the proportion of schizophrenic patients in Social Classes I and II is less than, and the proportion in Social Class $V$ is the same as, the corresponding proportions in the general population of the County of London. The social class distribution of the schizophrenic patients is not significantly different from that of the population of the County of London $(P>0.05)$. However, Blacker and Gore (1955) have shown that, for all types of patients admitted to the Bethlem Royal Hospital and the Maudsley Hospital, there is a much higher proportion of persons from Social Classes I and II than there is in the County of London as a whole. The social class distribution of our group of 126 schizophrenic patients is significantly different from that for all patients admitted to the Joint Hospital, in that the proportion of persons in Social Classes I and II is less and that in Social Classes IV and V is greater in the former than in the latter.

Studies of mental hospital admissions in England and Wales have been made by the Registrar-General (1955), and by Carstairs, Tonge, O'Connor, and Barber (1955), each of whom found the proportion of schizophrenics in Social Class $\mathrm{V}$ to be considerably higher than that in the corresponding general popuse lation. The diverse results (shown in Table IV)?

TABLE IV

SOCIAL CLASS DISTRIBUTION OF SCHIZOPHRENIC PATIENTS COMPARED WITH THAT IN THE COUNTY OF LONDON

\begin{tabular}{|c|c|c|c|c|c|}
\hline \multirow{4}{*}{$\begin{array}{c}\text { Registrar- } \\
\text { General's } \\
\text { Social } \\
\text { Class }\end{array}$} & \multicolumn{5}{|c|}{ Percentage of Persons in each Social Class } \\
\hline & \multirow{3}{*}{$\begin{array}{l}\text { London } \\
\text { Admini- } \\
\text { strative } \\
\text { County* }\end{array}$} & \multicolumn{3}{|c|}{ Schizophrenic Patients } & \multirow{3}{*}{$\begin{array}{c}\text { All In- } \\
\text { Patients } \\
\text { Maudsley/ } \\
\text { Bethlem } \\
\text { Hospitals }\end{array}$} \\
\hline & & \multirow{2}{*}{$\begin{array}{l}\text { Present } \\
\text { Sample }\end{array}$} & \multicolumn{2}{|c|}{$\begin{array}{l}\text { Mental Hospital } \\
\text { Patients }\end{array}$} & \\
\hline & & & Short-Stayt & Long-Stayt & \\
\hline$\underset{\text { III }}{\text { II }}$ & $\begin{array}{r}4 \cdot 0 \\
13 \cdot 0 \\
54 \cdot 2 \\
11 \cdot 9 \\
16 \cdot 9\end{array}$ & $\begin{array}{r}0 \cdot 9 \\
7 \cdot 3 \\
57 \cdot 0 \\
18 \cdot 3 \\
16 \cdot 5\end{array}$ & $\begin{array}{r}1 \cdot 0 \\
2 \cdot 7 \\
44 \cdot 5 \\
16 \cdot 6 \\
35 \cdot 2\end{array}$ & $\begin{array}{r}0.9 \\
3 \cdot 7 \\
50 \cdot 9 \\
12 \cdot 8 \\
31 \cdot 6\end{array}$ & $\begin{array}{r}7 \cdot 6 \\
17 \cdot 5 \\
56 \cdot 9 \\
11 \cdot 1 \\
7 \cdot 0\end{array}$ \\
\hline
\end{tabular}

* Males over 15 years of age in the County of London (1951 Census. County of London volume)

t Samples of patients resident in four mental hospitals serving the London area (Carstairs and others, 1955).

I All in-patients treated in the Bethlem Royal Hospital and the Maudsley Hospital during the period 1949-51 for whom an occupation was recorded.

- Occupations classified approximately to the classification of the Registrar-General (1951):

I Higher Professions, Company Directors, High Civil Service Administrators, Officers in the Regular Services.

II Artists, Teachers, Librarians, Pharmacists, Social Workers, Ward Sisters, Owners (business firms).

III Skilled trades and Clerks.

IV Semi-skilled Workers.

V Unskilled Workers. 
underline the necessity for interpreting hospital statistics with great care unless one can be sure that the hospital sample studied is representative of all hospital in-patients in the corresponding area. In London, where there are relatively good facilities for in-patient psychiatric care outside the mental hospital service itself, even more caution than usual is required in the interpretation of results obtained from any single hospital or small group of hospitals.

The movement of schizophrenics up and down the social hierarchy (called "social mobility" by Glass, 1954) is of interest because it can be postulated that a schizophrenic illness might result in a deterioration of the patient's ability to maintain himself either in the social class of his parents or in that to which he has himself attained. Glass and Hall (1954) in a study of "Inter-Generation Changes in Status" have used a seven-point classification of social status. Our numbers are so small that it has been necessary to condense this to five groups roughly comparable to the social class groups of the Registrar-General. The status categories, $1 ; 2+3 ; 4+5 ; 6 ; 7$, of Glass and Hall (pp. 31 and 182) appear to be approximately equivalent to the Registrar-General's Social Classes I, II, III, IV, and V respectively. A sample of just under 3,500 men drawn from the population of

TABLE $\mathrm{V}^{*}$

PERCENTAGE DISTRIBUTION OF MALE SAMPLE ACCORDING TO SUBJECTS' AND SUBJECTS' FATHERS' STATUS CATEGORY

\begin{tabular}{|c|c|c|c|c|c|}
\hline \multirow{2}{*}{$\begin{array}{l}\text { Social Class of } \\
\text { Subjects' Fathers }\end{array}$} & \multicolumn{5}{|c|}{ Social Class of Subjects } \\
\hline & I & II & III & IV & $\mathbf{V}$ \\
\hline $\begin{array}{l}\text { I } \\
\text { II } \\
\text { III } \\
\text { IV } \\
\text { V }\end{array}$ & $\begin{array}{r}38 \cdot 8 \\
5 \cdot 7 \\
1 \cdot 2 \\
0.0 \\
0.0\end{array}$ & $\begin{array}{r}34 \cdot 8 \\
35 \cdot 1 \\
11 \cdot 2 \\
5 \cdot 4 \\
4 \cdot 4\end{array}$ & $\begin{array}{l}20 \cdot 2 \\
48 \cdot 1 \\
60 \cdot 8 \\
47 \cdot 9 \\
44 \cdot 7\end{array}$ & $\begin{array}{r}4 \cdot 7 \\
6 \cdot 3 \\
15 \cdot 9 \\
31 \cdot 2 \\
23 \cdot 5\end{array}$ & $\begin{array}{r}1 \cdot 5 \\
4 \cdot 8 \\
10 \cdot 9 \\
15 \cdot 5 \\
27 \cdot 4\end{array}$ \\
\hline
\end{tabular}

Figures derived from a two-stage, stratified, random sample of 9296 persons aged 18 years and over, drawn in June and August 1949 from the 'live' cards maintained in the various local offices of the National Registration System made by the Social Survey.

* Adapted from Glass and Hall (1954) p. 183.
England and Wales was used by Glass and Hall who classified the subjects according to $(a)$ their own social status, and $(b)$ that of their parents.

Table $V$ has been adapted from Glass, (1954, p. 183). The entries in the diagonal show the percentage of men who remained in the same social class group as their fathers, and the entries to the right of the diagonal show the percentage whose social class is lower in the scale than that of their fathers, while those to left show the percentage who have improved their social status.

A similar table, Table VI, has been drawn up for our sample, but because of the small size of the sample the entries show the actual number of patients in each cell instead of the percentages. In addition, the expected numbers, calculated on the basis of the data given by Glass and Hall, are shown. It has been necessary to combine Social Classes I and II and Social Classes IV and V because the numbers are too small to treat each of the five classes separately. Patients whose fathers were in Social Classes I and II show a significant deterioration $(P<0.01)$ in social status, only 21 per cent. remaining the same, whereas 48 per cent. of Glass and Hall's subjects remained in the same status group as their fathers. In Social Class III, 63 per cent. of the patients and 73 per cent. of the general population sample either remained in the same category or moved to a better status than their fathers; the corresponding figures for Social Classes IV and V were 62 per cent. of the patients and 51 per cent. of the general population. These differences are not significant. $(P>0.05)$.

Thus the patients for whom a schizophrenic illness is related to deterioration in social status are those whose parents were in Social Classes I and II. In Social Classes IV and V, the schizophrenics have in fact improved their social status over that of their fathers to a greater, but not significant, extent than corresponding members in the general population. Hollingshead, Ellis, and Kirby (1954) compared 25 schizophrenic patients, 25 psychoneurotic patients,

TABLE VI

RELATIONSHIP OF PATIENTS' SOCIAL STATUS WITH THAT OF THEIR FATHERS (COMPARISON OF OBSERVED WITH EXPECTED NUMBERS OF PATIENTS)

\begin{tabular}{|c|c|c|c|c|c|c|c|c|}
\hline \multirow{3}{*}{\multicolumn{2}{|c|}{$\begin{array}{l}\text { Social Class of } \\
\text { Patients' Fathers }\end{array}$}} & \multicolumn{6}{|c|}{ Social Class of Patients } & \multirow{3}{*}{ Total } \\
\hline & & \multicolumn{2}{|c|}{ I and II } & \multicolumn{2}{|c|}{ III } & \multicolumn{2}{|c|}{ IV and $V$} & \\
\hline & & \multirow{2}{*}{$\frac{\text { Observed }}{6}$} & \multirow{2}{*}{$\begin{array}{c}\text { Expected } \\
=11 \cdot 6 ; n=2\end{array}$} & \begin{tabular}{|c|} 
Observed \\
15
\end{tabular} & \multirow{2}{*}{$\frac{\text { Expected }}{12 \cdot 3}$} & \multirow{2}{*}{$\frac{\text { Observed }}{8}$} & \multirow{2}{*}{$\frac{\text { Expected }}{2 \cdot 9}$} & \\
\hline I and II.. & $\ldots$ & & & $\begin{array}{c}15 \\
P<0.01 \text { us }\end{array}$ & & & & 29 \\
\hline III & . & 2 & $6 \cdot 3$ & $x^{2}=5 ; n$ & $2 ; P>0.05$ & 19 & $13 \cdot 7$ & 51 \\
\hline IV and $V$ & . & 1 & $1 \cdot 4$ & $x^{2}=17 \cdot 6 ; n$ & $2 ; P^{13 \cdot 5}>0.05$ & 11 & $14 \cdot 1$ & 29 \\
\hline
\end{tabular}

$$
\stackrel{\text { ? }}{\text { s. }}
$$$$
\text { 응 }
$$ 
and sixty controls (not patients) with respect to social mobility measured by the social rating of the subject relative to that of his father. They found that the schizophrenic sample had moved upwards to a greater extent than either of the other two samples, but it is not possible to compare these results with our own as different criteria were used.

Table VII was compiled in order to determine whether the illness caused a deterioration in the type of work performed and whether the nature of the previous occupation played a part in the chance of resuming employment. In this connexion it is interesting to find that a comparison of the occupational status of patients before admission with that

TABLE VII

COMPARISON OF OCCUPATIONAL STATUS BEFORE ADMISSION AND AFTER DISCHARGE

\begin{tabular}{|c|c|c|c|c|c|c|c|}
\hline \multirow{2}{*}{$\begin{array}{c}\text { Before } \\
\text { Admis- } \\
\text { sion }\end{array}$} & \multicolumn{6}{|c|}{ After Discharge } & \multirow[b]{2}{*}{ All } \\
\hline & I and II & III & $\underset{\text { and } V}{\text { IV }}$ & $\begin{array}{l}\text { House- } \\
\text { wives }\end{array}$ & $\begin{array}{c}\text { Stu- } \\
\text { dents }\end{array}$ & $\begin{array}{l}\text { Unem- } \\
\text { ployed }\end{array}$ & \\
\hline $\begin{array}{c}\text { I } \\
\text { and II }\end{array}$ & $\begin{array}{c}8 \\
(89 \%)\end{array}$ & - & - & - & - & 1 & 9 \\
\hline III & - & $\begin{array}{c}45 \\
(78 \%)\end{array}$ & 4 & 1 & - & 7 & 57 \\
\hline $\begin{array}{c}\text { IV } \\
\text { and } V\end{array}$ & 1 & 7 & $\stackrel{20}{(59 \%)}$ & - & - & 6 & 34 \\
\hline $\begin{array}{l}\text { House- } \\
\text { wives }\end{array}$ & - & - & - & $\left(\begin{array}{c}7 \\
(70 \%)\end{array}\right.$ & - & 3 & 10 \\
\hline $\begin{array}{c}\text { Stu- } \\
\text { dents }\end{array}$ & 2 & - & 3 & - & 3 & 1 & 9 \\
\hline $\begin{array}{l}\text { Unem- } \\
\text { ployed }\end{array}$ & - & - & - & - & - & 5 & 5 \\
\hline All & 11 & 52 & 27 & 8 & 3 & 23 & 124 \\
\hline
\end{tabular}

after discharge reveals little difference. It can be seen that on the whole patients remain in the same category after discharge as they had been in before admission; in all, excluding five unemployed before admission and still so after discharge, 93 (78 per cent.) persons remained in the same category or improved their status after discharge relative to preadmission status (two students who moved up to Social Classes I and II were counted with three who remained as students, three who were students before admission and who were in Social Classes IV and V after discharge were regarded as having slid down the social scale).

(4) Employability of Ex-patients.-The length of time for which the patient was in employment $\overrightarrow{\widehat{D}}$ during the 5-year follow-up period in relation to the total possible time was used as an index of employability. For example, if the patient were out of hospital for 4 years and if he worked during 3 of these years, his employability ratio (E.R.) was said to be 75 per cent. If he were out of hospital for only one year and during the whole of that time he was able to work, his E.R. was 100 per cent. There is a highly significant $(P<0.0001)$ association between a good clinical outcome and a high employ ability ratio and the converse is also true (see Tablo VIII). Of those who had an E.R. of 0 per cent. (2 patients), 78 per cent. were assessed clinically ast unchanged or worse; of those with an E.R. between 75 per cent. and 100 per cent. (78 patients), the condition of 44 per cent. was assessed as recovered, 15 per cent. as having a residual defect, 18 per cent. as presenting mild psychotic symptoms, and 23 per cent. as unchanged or worse. Thus, of 56 patients either recovered or with a residual defect, 82 per cent.

TABLE VIII

EMPLOYABILITY IN RELATION TO CLINICAL ASSESSMENT AT END OF A 5-YEAR FOLLOW-UP PERIOD

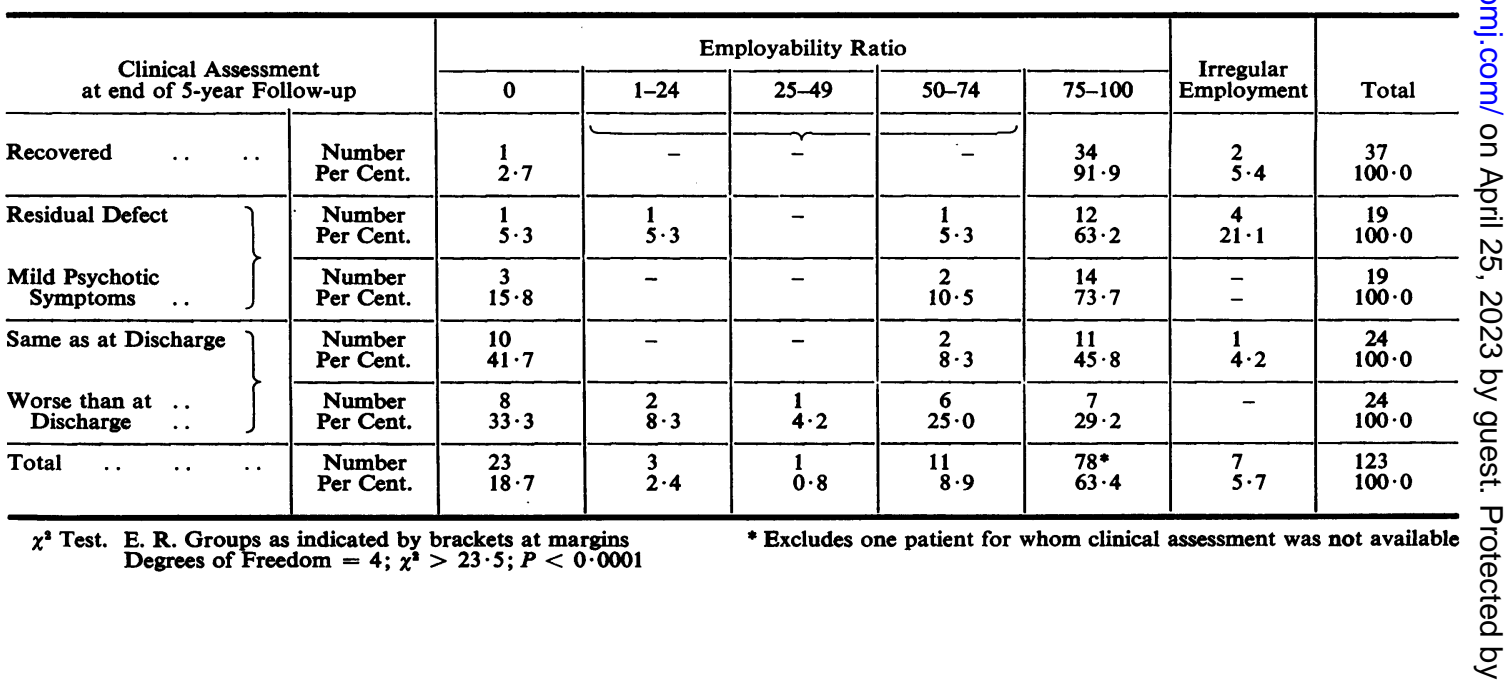


had an E.R. of 75 to 100 per cent. Of those who were said to be unchanged or worse (48), 37.5 per cent. also had an E.R. of 75 to 100 per cent. and, indeed, 54 per cent. were employed for at least half of the time they were out of hospital. In short, then, a substantial proportion of those whose clinical rating was poor were apparently able to work satisfactorily. This finding is of importance nowadays when there is a move to treat chronic mental patients out of hospital, but it depends to a considerable extent on the present conditions of full employment. Undoubtedly, the situation would not be so satisfactory if the level of employment in the country fell markedly. When the employability is compared with the length of hospitalization, it is found that all of the 23 patients with an E.R. of 0 per cent. stayed in hospital at least one year and 87 per cent. of them for at least 2 years, whereas 40 per cent. of those (79) who had an E.R. of 75 to 100 per cent. were never admitted during the follow-up period, 32 per cent. were in hospital for less than 1 year, 18 per cent. for at least 1 year but not as long as 2 years, and only 10 per cent. for 2 years or more. Of the fifteen persons whose E.R. fell between these extremes, 40 per cent. spent less than 2 years in hospital. These differences between the groups are highly significant $(P<0.0001)$.

We have already seen that clinical outcome is highly correlated with length of stay in hospital. Nearly all the patients clinically assessed as recovered or improved were employed for a large part of the time available to them, and it is likely that their employability was used implicitly in making the clinical assessment. In the group whose condition was assessed clinically as unchanged or worse (48 patients), seventeen were in hospital for less than 2 years; of these, twelve (71 per cent.) had an employability ratio of 75 per cent. or more and only one (6 per cent.) was not employed at all during the period available to him. On the other hand, of the remaining 31 patients who were in hospital for at least 2 years or more, only six (19 per cent.) had an employ- ability ratio of 75 per cent. or more, and seventeen (55 per cent.) were not employed at all during the period available to them. The differences between the short- and long-stay patients, who were assessed clinically as unrecovered, in respect of employability are highly significant $(P<0.001)$. It seems likely therefore that the period of time spent in hospital is of importance with regard to employment after discharge, independently of its associations with the clinical condition.

(5) Certification and Length of Stay in Hospital.It is sometimes thought that a certified person may have to stay in hospital longer than a voluntary patient, and indeed our figures bear out this supposition, for the differences between certified and voluntary patients with respect to duration of stay are highly significant $(P<0.001)$. Out of a total of 31 voluntary patients, 61 per cent. stayed for less than one year and only 10 per cent. for at least 3 years, whereas the corresponding figures for certified patients were 20 and 42 per cent. Nevertheless, of patients who spent only a short time in hospital (less than one year), one-third were certified, so that certification per se does not preclude a speedy recovery. Just under half of the certified, two-thirds of the voluntary patients, and nine-tenths of those who did not go into hospital during the follow-up period were employed for at least three-quarters of the time during which they were out of hospital. These figures all refer to mental hospital admissions during the follow-up period (Table IX).

\section{Discussion}

In this series, duration of total stay in hospital during a follow-up period of 5 years is closely linked with the patient's clinical condition at the end of the period. This finding suggests that statistical studies measuring course and outcome in terms of hospital stay can, in fact, serve a useful purpose. The most interesting results are those relating social factors to outcome. An encouragingly high proportion of relatives were willing to have the patients home, even

TABLE IX

EMPLOYABILITY IN RELATION TO LEGAL STATUS DURING FOLLOW-UP PERIOD

\begin{tabular}{|c|c|c|c|c|c|c|c|c|c|}
\hline \multirow{2}{*}{\multicolumn{3}{|c|}{$\begin{array}{l}\text { Legal Status } \\
\text { during Hospitalization }\end{array}$}} & \multicolumn{5}{|c|}{ Employability Ratio } & \multirow{3}{*}{\begin{tabular}{|c|}
$\begin{array}{c}\text { Irregular } \\
\text { Employment }\end{array}$ \\
1 \\
$1 \cdot 8$ \\
\end{tabular}} & \multirow{3}{*}{$\begin{array}{l}\text { Total } \\
56 \\
99.9\end{array}$} \\
\hline & & & \multirow{2}{*}{$\begin{array}{c}0 \\
32\end{array}$} & \multirow{2}{*}{$\frac{.1-24}{\frac{2}{3 \cdot 6}}$} & \multirow{2}{*}{$\overbrace{1}^{25-49}$} & \multirow{2}{*}{$\frac{50-74}{8}$} & \multirow{2}{*}{$\begin{array}{c}75-100 \\
26 \\
46.4\end{array}$} & & \\
\hline Certified Patients & $\cdots$ & $\begin{array}{l}\text { Number } \\
\text { Per Cent. }\end{array}$ & & & & & & & \\
\hline Voluntary Patients & $\cdots$ & $\begin{array}{l}\text { Number } \\
\text { Per Cent. }\end{array}$ & $\stackrel{5}{14 \cdot 7}$ & 1 & - & $\begin{array}{l}2 \\
5 \cdot 9\end{array}$ & 22 & $11 \cdot 8$ & $\begin{array}{c}34 \\
100 \cdot 0\end{array}$ \\
\hline Not Hospitalized & $\ldots$ & $\begin{array}{l}\text { Number } \\
\text { Per Cent. }\end{array}$ & $\overline{-}$ & - & $\overline{-}$ & $\begin{array}{l}1 \\
2 \cdot 9\end{array}$ & $\begin{array}{l}31 \\
91 \cdot 2\end{array}$ & $\begin{array}{l}2 \\
5 \cdot 9\end{array}$ & $100 \cdot 0$ \\
\hline
\end{tabular}

When employability ratio is grouped as marked: Degrees of Freedom $=4: x^{2}=23 \cdot 0 ; P=0 \cdot 0001$ 
though they were or had been dangerous either to themselves or to others or were exhibiting socially embarrassing symptoms. On the whole, however, such patients tend to remain in hospital longer than others.

When the social status of the patients was compared with that of their parents, 59 , per cent. either kept within the same social class status or improved upon their parents in this respect. Glass and Hall (1954) estimated that the corresponding figure in the general population was $71 \cdot 8$ per cent. But it is only among patients whose parents were in Social Classes I and II that this downward trend is marked. Indeed, among patients whose parents were in Social Classes IV and $\mathrm{V}$, there was a higher percentage of persons with an upward trend ( 62 per cent.) than in a corresponding section of the general population (51 per cent.), but this difference is not statistically significant. In view of the established genetical basis of schizophrenia (Mayer-Gross, Slater and Roth, 1954), it may be that a familial tendency to this disease might account to some extent for the unduly high representation of the lower social classes among schizophrenic patients. The family "prestige" may degenerate with each successive schizophrenic generaation until it reaches the bottom, when, of course, further deterioration is impossible and any change in status can only be an improvement.

The extent to which a patient was able to take up employment was related to his clinical condition and the length of time he had spent in hospital during the 5-year follow-up period, though rather more closely to the latter than the former; persons with a good clinical rating who were not in hospital for longer than one year apparently found little difficulty in maintaining themselves in employment while they were out of hospital. Conversely, the employment record of the patients who showed clear evidence of psychosis at the end of the follow-up period and who had spent a long period in hospital was not good. Nevertheless, over one-third of the patients who presented clear evidence of psychiatric abnormality were able to stay in employment for over threequarters of the time available to them in the followup period. Although certified patients stayed in hospital longer than voluntary patients, as many as one-third of the patients remaining in hospital for less than one year were certified.

\section{SUMmaRY}

A total of 126 patients who had had schizophrenic illnesses treated with insulin coma were followed up as completely as possible for a period of 5 years after their discharge from the Maudsley Hospital. There was a high correlation between length of hospital stay during the 5-year period and clinical and social outcome. Previous findings based on records of inpatient treatment alone were largely confirmed. At the end of the follow-up period nearly a quarter of the patients were earning their living and socially independent, in spite of giving persistent evidence of psychosis.

We are indebted to the Medical Superintendents of mental hospitals and other doctors who have supplied us with information, and to the Board of Governors of the Bethlem Royal Hospital and the Maudsley Hospital, whose enlightened policy in establishing a special followup office has provided us with the facilities for this work.

\section{REFERENCES}

Blacker, C. P., and Gore, A. T. (1955). "The Bethlem Royal Hospita and the Maudsley Hospital. Triennial Statistical Report. 1949-51"O London.

Carstairs, G. M., Tonge, W. L., O'Connor, N., and Barber, L. E. D (1955). British Journal of Preventive \& Social Medicine, 9, 187.

Dunham, H. W., and Meltzer, B. N. (1946). Amer. J. Sociol., 52, 123

Fuller, R. G., and Johnston, M. (1931). Psychiat. Quart., 5, 341 and 552.

Glass, D. V., ed. (1954). "Social Mobility in Britain". Routledge and Paul, London.

and Hall, J. R. (1954). Ibid., p. 182.

Harris, A., and Lubin, A. (1952). Mschr. Psychiat. Neurol., 124, 126. - and Norris, V. (1954). J. ment. Sci., 100, 727.

- (1955). Psychiat. Quart., 29, 33.

Hollingshead, A. B., and Redlich, F. C. (1953). Amer. sociol. Rev., $18,163$.

18. (1954a). Ibid., 19, 302. (1954b). Amer. J. Psychiat., 110, 695.

., Ellis, R., and Kirby, E. (1954). Amer. sociol. Rev., 19, 577. Malzberg, B. (1940). "Social and Biological Aspects of Mentai Disease". State Hospitals Press, Utica, N.Y.

Mayer-Gross, W., Slater, E., and Roth, M. (1954). “Clinical Psychiatry". Cassell, London.

Mettler, F. A., Crandell, A., Wittenborn, J. R., Litten, K., Feiring, E. H., and Carpenter, M. B. (1954). Psychiat. Quart., 28, 549. Ødegaard, O. (1954). Ment. Hyg. (N.Y.), 38, 447.

Orr, W. F., Anderson, R. B., Martin, M. P., and Philpot, D. F. (1955). Amer. J. Psychiat., 11i, 576.

Registrar-General (1951). "Classification of Occupations, 1950". H.M.S.O., London.

H.M.1955), "Statistical Review of England and Wales for the Years 1950-51. Supplement on General Morbidity, Cancer and Mental Health". H.M.S.O., London. 